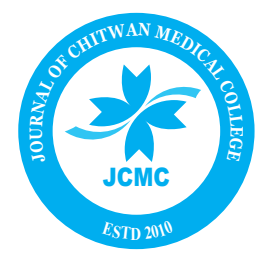

\author{
Journal of Chitwan Medical College 2020;10(31):78-81 \\ Available online at: www.jcmc.cmc.edu.np
}

\title{
FEMALE AUTONOMY AND FERTILITY PATTERN AMONG WOMEN WORKING IN FORMAL SECTOR IN KATHMANDU VALLEY
}

\author{
Neeti Singh ${ }^{1,{ }^{*}}$, Srijana Pandey ${ }^{1}$, Ang Tshering Sherpa ${ }^{1}$, Nijina Tamrakar ${ }^{2}$, Sunil Chitrakar ${ }^{1}$ \\ ${ }^{1}$ Department of Community Medicine, KISTMCTH, Imadole, Lalitpur, Nepal \\ ${ }^{2}$ Kirtipur hospital, Kirtipur Municipality, Kathmandu, Nepal
}

\begin{abstract}
Received: 5 Jan, 2020
Accepted: 11 Mar, 2020

Published: 13 Mar, 2020

Key words: Fertility pattern; Formal sector; Working women

*Correspondence to: Neeti Singh, Department of

Community Medicine, KIST Medical College and

Hospital, Imadole, Kathmandu, Nepal.

Email: neetiis@gmail.com

DOI:https://doi.org/10.3126/jcmc.v10i1.28078

Citation

Singh N, Pandey S, Sherpa AT, Tamrakar N, Chitrakar S. Female autonomy and fertility pattern among women working in formal sector in Kathmandu valley.Journal of Chitwan Medical College.2020;10(31):78-81.

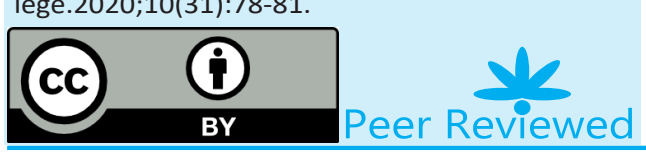

\section{INTRODUCTION}

Total fertility rate (TFR) means total number of children born or likely to be born to a woman in her life time if she were subject to the prevailing rate of age-specific fertility in the population (WHO,2019). ${ }^{1}$ TFR of about 2.1 children per woman is called Replacement-level fertility. ${ }^{2}$ The number of children a woman bears depends upon various factors like the age at marriage, preferred gap, and her fecundity. ${ }^{3}$ Education, changing family structure and socioeconomic status also plays vital role in fertility pattern. ${ }^{4}$ In Nepal, overall fertility rate of women is declining in past few years. This is considered good sign for the health of mother in a country where teenage marriage and pregnancy is prevalent. This declination is seen more among urban women than rural woman. ${ }^{5}$ Contributing factors included level of education, lifestyle, late age at marriage, late age at first conception and preference of children. ${ }^{5-7}$

Desire to attain higher education may delay the age at marriage. Decrease in drastic fertility rate may in long run influence the development of the country. So, this study was done to explore the fertility pattern among working women and the associated factors.

\section{METHODS}

An observational study was done among women working at formal sectors in Kathmandu valley. Structured elf administered questionnaire was used to collect data. The questionnaire is adapted from the tool used by Nepal demographic health survey 2016 to assess fertility pattern among Nepalese population. ${ }^{5}$ The selection of place was done purposively selecting national capital where most women are inclined to all fields of works and higher educational attainment compared to rest of the country. The study included women working at formal sectors, both private and public (government sector), with fixed monthly income with or without living children. Selection of women was done by respondent driven sampling (RDS) method. Working women in formal sector was approached in a referral basis from one working women to another. Each woman was asked to refer at least two working women within reproductive age group within their acquaintance. The process was continued till the sample size was achieved. The total sample size was 101 and the study duration was October and November 2019. Verbal Consent was taken from all participants after explaining the purpose of study. The variables included were age at marriage, education, number of children, prefer- 
ence of number of children, use of family planning method and birth spacing between two children.

Sample Size Calculation:

Using the formula $=Z^{2} p q / d^{2}$, Where, $Z=1.96, P=50 \%, q=50$, $d=10$, the sample size was 96.04 . With addition of $5 \%$ nonresponse rate, the sample size ultimately calculated was 101.

\section{RESULTS}

There were total 101 working women in formal sector with fixed monthly income participating in the study. The women were within reproductive aget group (20yrs. to $49 \mathrm{yrs}$.). The mean age of the participants was 39.38yrs (SD \pm 5.99$)$ with median age of 40 years. All the women were working at the time of marriage.

Table 1A: Demographic characteristics

\begin{tabular}{|c|c|}
\hline Characteristics & $\begin{array}{c}\text { Frequency } \\
(\%)\end{array}$ \\
\hline \multicolumn{2}{|l|}{ Age group (in years) } \\
\hline$>30$ & $5(5)$ \\
\hline $30-34$ & $21(20.8)$ \\
\hline $35-39$ & $24(23.8)$ \\
\hline $40-44$ & $25(24.8)$ \\
\hline $45-49$ & $26(25.7)$ \\
\hline \multicolumn{2}{|l|}{ Religion } \\
\hline Hindu & $88(87.1)$ \\
\hline Buddhist & $12(11.9)$ \\
\hline Others & $1(1)$ \\
\hline \multicolumn{2}{|l|}{ Ethinicity* } \\
\hline Upper caste & $40(39.6)$ \\
\hline Relatively advantaged Janjati & $48(47.5)$ \\
\hline Disadvantaged Non-Dalit terai caste & $2(2)$ \\
\hline Religious minorities & $1(1)$ \\
\hline Disadvantaged Janjati & $10(9.9)$ \\
\hline \multicolumn{2}{|l|}{ Education } \\
\hline Primary & $1(1)$ \\
\hline Secondary & $2(2)$ \\
\hline Higher secondary & $7(6.9)$ \\
\hline Bachelors & $34(33.7)$ \\
\hline Masters & $56(55.4)$ \\
\hline $\mathrm{PhD}$ & $1(1)$ \\
\hline \multicolumn{2}{|l|}{ Occupation } \\
\hline $\begin{array}{l}\text { Executive/Manager/ Senior level officer } \\
\text { (Government Job) }\end{array}$ & $18(17.8)$ \\
\hline $\begin{array}{l}\text { Executive/Manager/ Senior level officer (Private } \\
\text { Job) }\end{array}$ & $20(19.8)$ \\
\hline Teacher in school/college & $16(15.8)$ \\
\hline Office Assistant & $15(14.9)$ \\
\hline $\begin{array}{l}\text { Highly skilled professionals (Doctor/Dental } \\
\text { surgeon/Engineer }\end{array}$ & $32(31.7)$ \\
\hline
\end{tabular}

Most of the participants were above 29 years of age (95\%). More than $87 \%$ of the participants were Hindus, belonged to upper caste group (39.6\%) and relatively advantaged janjati (47.5\%) group (Table $1 \mathrm{~A})$.
Regarding education level, most participants attained bachelors and above (96\%). Similarly, $31.7 \%$ of the participants belonged to highly skilled professional group such as doctor, engineer and dental surgeons (Table $1 \mathrm{~A}$ ).

Table 1B: Demographic characteristics

\begin{tabular}{|c|c|}
\hline Characteristics & Frequency (\%) \\
\hline \multicolumn{2}{|l|}{ Age at marriage (in years) } \\
\hline$<25$ & $47(46.5)$ \\
\hline $25-29$ & $43(42.5)$ \\
\hline $30-34$ & $9(8.9)$ \\
\hline $35-39$ & $1(1)$ \\
\hline $40-44$ & $1(1)$ \\
\hline Median age at marriage & 26.62 years \\
\hline \multicolumn{2}{|l|}{ Age of Husband at marriage (in years) } \\
\hline $24-29$ & $11(10.9)$ \\
\hline $30-34$ & $52(51.5)$ \\
\hline $35-39$ & $34(33.7)$ \\
\hline $40-44$ & $3(3)$ \\
\hline $45-49$ & $1(1)$ \\
\hline \multicolumn{2}{|l|}{ Age (in years) at completion of last degree } \\
\hline$<25$ & $31(30.7)$ \\
\hline $25-29$ & $30(29.7)$ \\
\hline $30-34$ & $27(26.7)$ \\
\hline $35-39$ & $10(9.9)$ \\
\hline$\geq 40$ & $3(3)$ \\
\hline Mean age at completion of last degree & 27.79 years \\
\hline \multicolumn{2}{|l|}{ Educational level of husband } \\
\hline Up to higher secondary level & $12(11.9)$ \\
\hline Bachelors and above & $89(88.1)$ \\
\hline \multicolumn{2}{|l|}{ Educational level of husband at marriage } \\
\hline Up to higher secondary level & $14(13.9)$ \\
\hline Bachelors and above & $87(86.1)$ \\
\hline \multicolumn{2}{|l|}{ Educational level of Father } \\
\hline Up to higher secondary level & $48(47.5)$ \\
\hline Bachelors and above & $53(52.5)$ \\
\hline \multicolumn{2}{|l|}{ Educational level of Mother } \\
\hline Up to higher secondary level & $72(71.3)$ \\
\hline Bachelors and above & $29(28.7)$ \\
\hline
\end{tabular}

In this study, $89 \%$ of the working women were married before 30 years of age, the median age at marriage being 26.62 years. More than $87 \%$ of the respondents completed their last degree by the age of 34 years (mean age $=27.79$ years SD \pm 5.47 ) In contrary, more than half $(51.5 \%)$ of the husband's age at marriage was within 30 years to 34 years age group (Table1B).

The study revealed that educational level of husband at marriage was almost same as current education level, $86.1 \%$ and $88.1 \%$ respectively. Regarding parent's education, only $28.1 \%$ mothers attained bachelors or more whereas $52.5 \%$ fathers attained bachelors or more (Table 1B). 
Table 2: Fertility behavior of working women

\begin{tabular}{|c|c|}
\hline Characteristics & $\begin{array}{c}\text { Frequency } \\
(\%)\end{array}$ \\
\hline \multicolumn{2}{|l|}{ Age at first pregnancy } \\
\hline$<35$ years & $99(98)$ \\
\hline$\geq 35$ years & $2(2)$ \\
\hline Median age at first pregnancy & 27years \\
\hline \multicolumn{2}{|l|}{ Number of abortions } \\
\hline 1 & $15(65.2)$ \\
\hline 2 or more & $8(34.8)$ \\
\hline \multicolumn{2}{|l|}{ Number of children } \\
\hline None & $5(5)$ \\
\hline 1 & $59(58.4)$ \\
\hline 2 or more & $37(36.6)$ \\
\hline \multicolumn{2}{|l|}{ Desired number of children } \\
\hline 1 & $35(34.7)$ \\
\hline 2 & $64(64.3)$ \\
\hline 3 & $2(2)$ \\
\hline \multicolumn{2}{|l|}{ Decision on number of children } \\
\hline Husband/wife & $9(9.1)$ \\
\hline Both & $92(92.9)$ \\
\hline \multicolumn{2}{|c|}{ Current use of contraceptive devices } \\
\hline No & $65(65.6)$ \\
\hline Yes & $36(36.4)$ \\
\hline
\end{tabular}

In this study, $98 \%$ of working women had first pregnancy at age less than 35 years with median age being 27 years. Only 23 women gave history of abortion. Similarly, $58.4 \%$ of women had one living child and $36.6 \%$ had 2 or more children. More than $66 \%$ of women reported to had desired 2 or more children. Only $34.7 \%$ reported that they desired single child. More than $90 \%$ of the couple made joint decision on number of children (Table 2).

On knowledge about family planning, all women were aware about different types of contraceptive devices. But only $35.6 \%$ of women were using some form of devices as the measure of family planning (Table 2 ).

In this study, higher the level of education attained, the age at marriage was increased and was statistically significant ( $p$ value<0.05) (Table 3).

The study result showed that there is a gap between the number of children and desired number of children among the participants and is statistically significant ( $p$ value $<0.05$ ) (Table 4).

The women who completed their last degree at higher age had late first pregnancy. The relation between two was statistically significant ( $p$ value<0.05) (Table 5).

Table 3: Relation between age at marriage and education level at marriage

\begin{tabular}{|l|c|c|c|c|c|c|}
\hline \multirow{2}{*}{ Education level at marriage } & \multicolumn{5}{|c|}{ Age at marriage(in years) } & \multicolumn{2}{c|}{$\mathbf{~}$-value } \\
\cline { 2 - 7 } & $\mathbf{2 4}$ & $\mathbf{2 5 - 2 9}$ & $\mathbf{3 0 - 3 4}$ & $\mathbf{3 5}-\mathbf{3 9}$ & $\mathbf{2 0}$ & $\mathbf{0}$ \\
\hline Primary level & 1 & 0 & 0 & 0 & 0 \\
\hline Secondary & 3 & 0 & 0 & 0 & 0 \\
\hline Higher secondary & 19 & 3 & 1 & 0 & 0 \\
\hline Bachelors & 22 & 25 & 7 & 0 & 0 \\
\hline Masters & 2 & 15 & 1 & 1 & 1 \\
\hline
\end{tabular}

Table 4: Number of children and desired number of children

\begin{tabular}{|c|c|c|c|c|c|}
\hline \multirow{2}{*}{ Desired number of children } & \multicolumn{3}{|c|}{ Number of live children } & \multirow{2}{*}{ Total } & \multicolumn{2}{c|}{$p$-value } \\
\cline { 2 - 5 } & 0 & 1 & 2 & 35 & 64 \\
\hline 1 & 3 & 0 & 35 & 6.0001 \\
\hline 2 & 2 & 27 & 0 & 2 & \\
\hline 3 & 0 & 2 & 2 & 2 \\
\hline
\end{tabular}

Table 5: Age at completion of last degree and Age at first pregnancy

\begin{tabular}{|c|c|c|c|c|c|}
\hline \multirow{2}{*}{ Age at completion of last degree (in years) } & \multicolumn{4}{|c|}{ Age at first pregnancy (in years) } \\
\cline { 2 - 6 } & $<29$ & $30-34$ & $35-39$ & $\geq 40$ & 0 \\
\hline$<25$ & 21 & 9 & 1 & 1 \\
\hline $25-29$ & 14 & 15 & 0 & 1 \\
\hline $30-24$ & 10 & 13 & 3 & 1 & \\
\hline
\end{tabular}

The women who completed their last degree at higher age had significant ( $p$ value<0.05) (Table 5). late first pregnancy. The relation between two was statistically 


\section{DISCUSSION}

Fertility pattern among women decrease with age. According to NDHS, the median age at first marriage is 17.9 years among women and 21.7 years among men age $25-49 . .^{5}$ In this study median age at marriage was 25 years which was more than 4 years higher than national figure. This adds to the evidence that states educational attainment and autonomy of women plays major role in increased age at marriage. In Nepal, women with an SLC or higher degree married almost 5 years later than women with no education. ${ }^{5}$ In this study median age at marriage was found to be more than a year higher $(26.62$ years ) among those working as highly skilled technical group (doctors, dental surgeons, engineers ) than those from other skilled group. This may be due to duration of study and formal time needed to dedicate in gaining skill is longer in this group than others. The study also showed that age at marriage is higher among those with higher education and was statistically significant ( $p$ value $=0.001$ ). The result is similar to other studies which states that there has been a downward trend regarding the number of children of women with higher education..$^{8,9}$ Women with 12 or more years of schooling have a $21 \%$ lower incidence rate ratio compared to those who have less than one year of schooling. ${ }^{9}$

Number of children per woman declines with increasing education. According to household bargaining model, more educated women are better able to support themselves and have more bargaining power, including on family size. ${ }^{10}$ According to Nepal Demographic Health Survey 2016, women in Nepal with no education have 3.3 children on average, as compared with 1.8 children among women with an SLC or more. ${ }^{5}$ In this study, average number of live children was 1.32. In contrary, another study concludes that fertility behavior of women is

\section{REFERENCES:}

1. WHO. Health situation and trend assessment. SEARO.2019. [LINK]

2. Craig J. Replacement level fertility and future population growth. Popul Trends. 1994;(78):20-2. [PMID]

3. Adhikari R. Demographic, socio-economic, and cultural factors affecting fertility differentials in Nepal. BMC Pregnancy and Childbirth.2010;10(19):1-11. [LINK]

4. Batyra E. Fertility and the changing pattern of the timing of childbearing in Colombia. Demographic Research.2016;35 (46):1343-72. [LINIK]

5. Ministry of Health, Nepal, New ERA, ICF. Nepal Demographic and Health Survey 2016. Kathmandu, Nepal: Ministry of Health, Nepal. 2017(Nov);103-113.

6. Nepal Demographic and Health Survey (NDHS). Ministry of Health and Population (MOHP), Nepal, New ERA and Macro International Inc. 2016. [LINK]

7. Ariho $P$, KabagenyiA,Nzabona A. Determinants of change in fertility pattern among women in Uganda during the period 2006-2011. Fertil Res Pract. 2018 Jun;4(4):1-11. [LINK] not influenced by their working status except for higher age at first cohabitation with husbands due to delayed marriage and increased levels of knowledge of contraception particularly of spacing methods. ${ }^{11}$

Unmet need to desired number of children may be affected by various factors such as education level of husband and wife, age at marriage, work commitment, knowledge on high risk pregnancy and income. ${ }^{12,13}$ In this study, average number of desired children was 1.69 which was higher than actual number of live children among respondents (1.32). The gap may be due to higher age at first pregnancy and attainment of higher education after marriage.

This study reports that only $19.8 \%$ participants attained master level at the time of marriage whereas $56.4 \%$ respondent's current education status was masters and above. So, continuation of higher education may have influenced in fulfillment of desired number of children.

\section{CONCLUSION}

This study concludes that fertility behavior of women is not completely influenced by either their or husband's working status except for higher age at marriage and pregnancy. There was wide gap existing between awareness and practices of contraception. But still there is gap between desired and actual number of live children. So, it is grave need to ensure utilization of services that can yield desired outputs in terms of change in fertility preferences.

\section{CONFLICT OF INTEREST: None}

\section{FINANCIAL DISCLOSURE: None}

8. Moradi M, Kariman N,Simbar M, PourhoseingholiMA, Baki S.The factors associated with childbearing intentions in Iranian female University students. Annals of tropical medicine and public health.2017;10(6):1714-19. [LINK]

9. Tejada CAO,Triaca LM, Katrein da Costa F,Hellwig F. The socio-demographic, behavioral, reproductive, and health factors associated with fertility in Brazil. PLoS One. 2017; 12(2):1-10. [LINK]

10. Karra M, Canning D, Wilde J.The Effect of Fertility Decline on Economic Growth in Africa: A Macrosimulation Model.Population and development review.2017 Jan ;237-63. [LINK]

11. Female age-related fertility decline. Committee Opinion. The practice committee of the American society for reproductive medicine.2014 march;589. [LINK]

12. Akmam W. Women's Education and Fertility Rates in Developing Countries, With Special Reference to Bangladesh. Eubios Journal of Asian and International Bioethics.2002;12: 138-143. [LINK]

13. Kumar D, Goel N, Mittal P, Srivastava P. Working status of women and their fertility pattern in an urban community. The internet journal of health.2007:8(1):1-5. [LINK] 